\title{
Visualization of Foundation Evaluation for Urban Rail Transit Based on CGB Technology Integration
}

\author{
Lili Dong ${ }^{1,2}$, Jin $\mathrm{Wu}^{2}$, Wei Wang ${ }^{3 *}, \mathrm{Yu} \mathrm{Zhou}^{2}$ \\ ${ }^{1}$ School of Architecture and Urban Planning, Chongqing University, Chongqing 400030, China \\ ${ }^{2}$ School of Architecture and Urban Planning, Chongqing Jiaotong University, Chongqing 400074, China \\ ${ }^{3}$ School of Art, Design and Architecture, University of Huddersfield, HD1 3DH, West Yorkshire, United Kingdom
}

Corresponding Author Email: wangwei19930801@foxmail.com

https://doi.org/10.18280/ijsdp.150408

Received: 28 January 2020

Accepted: 1 April 2020

\section{Keywords:}

$C G B$ technology integration, foundation evaluation, analytic hierarchy process $(A H P)$, visualization

\begin{abstract}
In urban rail transit projects, the traditional method of foundation evaluation faces problems like vague description, unclear process, and fuzzy evaluation system. To solve these problems, this paper sets up a scientific evaluation system based on CGB technology integration and analytic hierarchy process (AHP). The CGB technology integration refers to the integrated application of computer-aided design (CAD), geographic information system (GIS), and building information modeling (BIM). Taking Qingxihe Station, Line 6 of Chongqing Rail Transit (CRT) as the object, the authors constructed a 3D geological model of the construction site, created a novel three-layer system through data analysis, and evaluated and compared the suitability of each layer as the supporting layer of the foundation. Finally, effective suggestions were put forward on the selection of the supporting layer. Our research successfully visualizes the whole process of foundation evaluation, and enhances the accuracy of the evaluation results. The research findings provide a good reference for the selection of the supporting layer of foundations in urban rail transit projects.
\end{abstract}

\section{INTRODUCTION}

The CGB technology integration refers to the integrated application of computer-aided design (CAD), geographic information system (GIS), and building information modeling (BIM). To meet the various needs of urban digitalization, the CGB technology integration jointly utilizes macro-geographic information and micro-building information, facilitating queries and analyses [1].

Compared with the CAD data, the BIM data and GIS data are not highly compatible. To share and merge these data, it is necessary to explore the industry foundation classes (IFC) model of the BIM and the CityGML model of the GIS, and develop a method capable of automatically extracting the GIS surface model with multiple levels of details (LODs) from the BIM entity model. In this way, the LOD 100-400 models could be obtained from the IFC and CityGML model, overcoming the difficulty in merging the BIM with the GIS and paving the way for the CGB technology integration [2-14].

The BIM and GIS are the two most popular digital technologies in the research of urban rail transit. For instance, D'Amico et al. [15] integrated the BIM with the GIS into the design of transport infrastructure, and suggested that the interoperable sharing models supplemented by the GIS data could minimize or eliminate the possible conflicts between infrastructure design and environmental constraints. Liu et al. [16] fully utilized the advantages of the BIM (e.g. 3D visualization, parametrization, and virtual simulation) to solve foundation engineering, a basic problem in rail transit, and thus improved the quality and efficiency of metro construction. Chen et al. [17] realized the conversion between geometric and semantic information through the BIM and 3D GIS data exchange method of rail transit, and defined an integrated 3D spatial data model, achieving unified management and seamless expression of the data on rail transit and its surroundings. He et al. [18] displayed and analyzed the spatial distribution of unfavorable geological bodies in the GIS, evaluated the karst collapse risk in the area crossed by the tunnel, and assessed the safety risk of metro tunnel on the BIM platform based on construction and monitoring information, laying the basis for tunnel safety prewarning.

Based on CGB technology integration and analytic hierarchy process (AHP), this paper develops a scientific method to visualize the foundation evaluation in urban rail transit projects. Qingxihe Station, Line 6 of Chongqing Rail Transit (CRT) was taken as the research case to evaluate the suitability of different layers to serve as the support layer of the foundation. The authors detailed the selection of evaluation method and the establishment of evaluation system, and verified the proposed method through case analysis, shedding new light on the visualization of the results of engineering geological investigation.

\section{CGB-BASED VISUALIZATION OF FOUNDATION EVALUATION}

In engineering geological investigation, engineering geological evaluation is one of the key contents. The utmost goal of engineering geological investigation lies in foundation evaluation, a part of engineering geological evaluation. Through foundation evaluation, the suitability of each layer as 
the supporting layer of the foundation could be quantified. The CGB technology integration provides a desirable tool to visualize the foundation evaluation. As shown in Figure 1, the CGB-based visualization of foundation evaluation mainly acquires the spatial distribution of the geological information in the construction site through investigation and field survey, models the spatial situation with discrete data points, and then analyzes the geological data using the information retrieval and processing functions of CGB technology integration [1926].

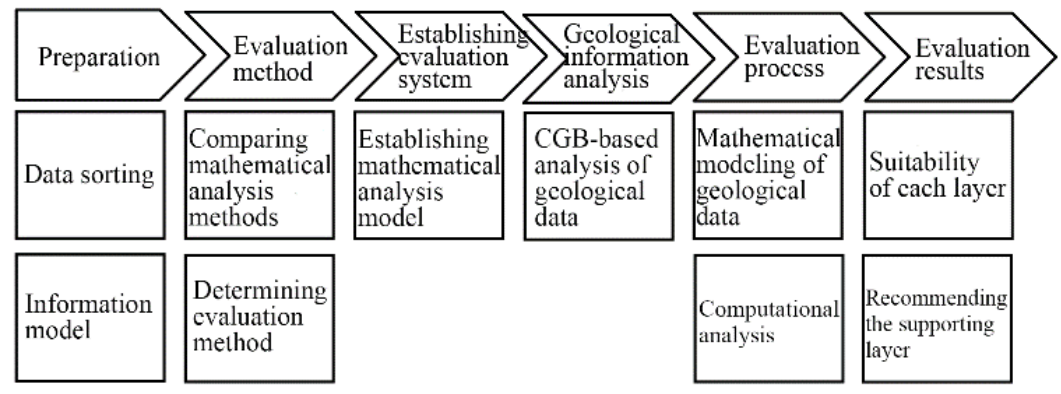

Figure 1. The roadmap of CGB-based visualization of foundation evaluation

\subsection{Selection of evaluation method}

According to the response from construction parties, there are several problems with the current method for foundation evaluation: the foundation quality is described vaguely by qualitative words (e.g. general, good, and poor), without any quantitative comparison; the evaluation items are complex and not weighted; the evaluation process and results derivation are not visible. To solve these problems, the AHP was introduced to provide a multi-factor evaluation system for foundation evaluation, and fully integrate qualitative analysis with quantitative analysis.

\subsection{Establishment of evaluation system}

\section{(1) Level division}

The contents of foundation evaluation were divided as per the requirements of relevant codes. According to the goal, items, and objects of foundation evaluation, a multi-layer evaluation model was established, in which each layer controls and is controlled by its upper and lower layers. As shown in Figure 2, the established model consists of the goal layer (evaluation goal), the criteria layer (evaluation items), and the alternative layer (evaluation objects).

(2) Construction of judgment matrix for pairwise comparison

Once the evaluation model is established, it is necessary to determine the judgment matrix of each layer, that is, to judge the relative importance of each factor on each layer and express it as a numerical value. Based on the hierarchy of the three layers, it is also necessary to determine the importance of each factor on the lower layer relative to each relevant factor on the upper layer (goal A or criterion Z). Suppose factor $A_{k}$ on layer $\mathrm{A}$ is correlated with factors $B_{1}, B_{2}, \ldots, B_{n}$ on the lower layer. Then, the judgement matrix of layer $\mathrm{A}$ can be constructed as Table 1 , where $A_{k}$ is the numerical value of the importance of $B_{i}$ relative to $B_{j}$. The relative importance is usually rated against a nine-point scale (Table 2).

Table 1. The judgement matrix

\begin{tabular}{ccccc}
\hline$A_{k}$ & $B_{1}$ & $B_{2}$ & $\ldots$ & $B_{n}$ \\
\hline$B_{1}$ & $b_{11}$ & $b_{12}$ & $\ldots$ & $b_{1 n}$ \\
$B_{2}$ & $b_{21}$ & $b_{22}$ & $\ldots$ & $b_{2 n}$ \\
$\vdots$ & $\vdots$ & $\vdots$ & $\vdots$ & $\vdots$ \\
$B_{n}$ & $b_{n 1}$ & $b_{n 2}$ & $\ldots$ & $b_{n n}$ \\
\hline
\end{tabular}

Table 2. The scale of importance

\begin{tabular}{|c|c|}
\hline Levels & Meanings \\
\hline 1 & Two factors are equally important. \\
\hline 3 & $\begin{array}{c}\text { The former factor is slightly more important } \\
\text { than the latter. }\end{array}$ \\
\hline 5 & $\begin{array}{l}\text { The former factor is strongly more important } \\
\text { than the latter. }\end{array}$ \\
\hline 7 & $\begin{array}{l}\text { The former factor is very strongly more } \\
\text { important than the latter. }\end{array}$ \\
\hline 9 & $\begin{array}{l}\text { The former factor is extremely more important } \\
\text { than the latter. }\end{array}$ \\
\hline $2,4,6,8$ & $\begin{array}{l}\text { The relative importance falls between two of } \\
\text { the above levels. }\end{array}$ \\
\hline $\begin{array}{l}\text { Reciprocals of } \\
\text { above }\end{array}$ & $\begin{array}{l}\text { If the importance of factor } i \text { relative to factor } j \\
\text { is } b_{i j} \text {, then the importance of factor } \mathrm{j} \text { relative to } \\
\text { factor } \mathrm{i} \text { is } b_{j i}=1 / b_{i j} \text {. }\end{array}$ \\
\hline
\end{tabular}

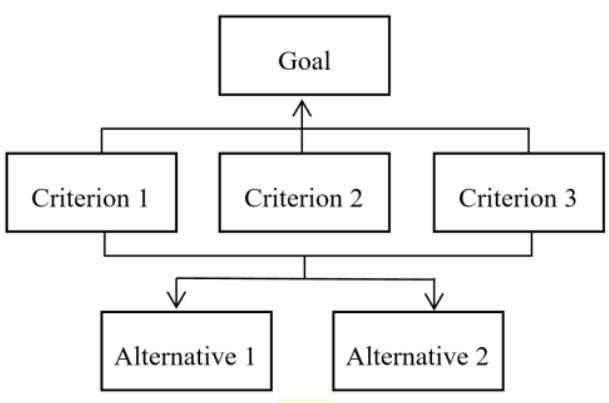

Figure 2. The multi-layer evaluation model

The judgment matrix must also satisfy:

$$
b_{i j}>0 ; b_{j i}=1 / b_{i j} ; b_{i i}=1(i=1,2, \cdots, n)
$$

Formula (1) shows that the judgement matrix is symmetric. In special cases, the judgment matrix must also be transitive:

$$
b_{i j} \cdot b_{j k}=b_{i k}
$$

(3) Single ranking

Single ranking is to sort the factors on a layer by the importance relative to each relevant factor on the upper layer. The single ranking is equivalent to the calculation of the characteristic roots and eigenvectors of the judgement matrix. In other words, judgement matrix $B$ should satisfy: 


$$
B W=\lambda_{\max } W
$$

where, $\lambda_{\max }$ is the maximum characteristic root of $B ; W$ is the normalized eigenvector corresponding to $\lambda_{\max } ; W_{i}$, a component of $W$, is the weight of factor $i$ in single ranking.

Besides, the consistency of the judgment matrix should be verified by computing its consistency index $C I$ :

$$
C I=\frac{\lambda_{\max }-n}{n-1}
$$

If the judgement matrix is fully consistent, $C I=1$; the greater the $\lambda_{\max }-n$, the larger the $C I$, and the less consistent is the judgement matrix. Since the sum of $\mathrm{n}$ eigenvalues of $B$ equals $\mathrm{n}, C I$ is equivalent to the mean of $n-1$ characteristic roots other than $\lambda_{\max }$.

Table 3. The mean random consistency index (RI)

\begin{tabular}{llllllllll}
\hline Order & 1 & 2 & 3 & 4 & 5 & 6 & 7 & 8 & 9 \\
\hline RI & 0.00 & 0.00 & 0.58 & 0.90 & 1.12 & 1.24 & 1.32 & 1.41 & 1.45 \\
\hline
\end{tabular}

When the order of the judgment matrix is greater than 2 (Table 3), the ratio of CI to RI (the mean random consistency index of the same order) is defined as the random consistency ratio (CR) of the matrix. If $C R \leq 0.01$, the judgement matrix has satisfactory consistency; Otherwise, the judgment matrix needs to be adjusted.

The consistency of overall ranking results should be verified in a similar manner. From top to bottom, the consistency needs to be checked layer by layer. Let $C I_{j}^{(k)}$ and $R I_{j}^{(k)}$ be the CI and $\mathrm{RI}$ of a factor on layer $\mathrm{k}$ relative to factor $j$ on layer $k-1$ in single ranking, respectively. Then, the CR of layer $k$ in overall ranking can be expressed as:

$$
C R^{(\mathrm{k})}=\frac{\sum_{j-1}^{n_{i}} w_{j}^{(k-1)} C I_{j}^{(k)}}{\sum_{j-1}^{n_{i}} w_{j}^{(k-1)} R I_{j}^{(k)}}
$$

Similarly, if $C R^{(k)} \leq 0.10$, the overall ranking results have satisfactory consistency.

(4) Overall ranking

Overall ranking is to sort the importance of all factors on the current layer relative to the superior layer, based on the single ranking results of the current layer relative to all the other layers. The overall ranking needs to be performed layer by layer from top to bottom. Suppose the importance ranking of the $\mathrm{n}$ factors on layer $\mathrm{k}-1$ relative to the goal layer satisfy:

$$
w^{(k-1)}=\left(w_{1}^{(k-1)}, \cdots, w_{n}^{(k-1)}\right)^{T}
$$

The single ranking vector of $n_{k}$ factors on layer $k$ relative to criterion $j$ on layer $k-1$ can be defined as:

$$
\begin{gathered}
\mathrm{u}_{\mathrm{j}}^{(k)}=\left(\mathrm{u}_{1 \mathrm{j}}^{(k)}, \mathrm{u}_{2 \mathrm{j}}^{(k)}, \cdots, \mathrm{u}_{\mathrm{n}_{\mathrm{i}} \mathrm{j}}^{(k)}\right)^{T} \\
j=1,2, \cdots, n ; k=1,2, \cdots, n_{k}
\end{gathered}
$$

The importance of factors not linked to criterion $j$ was set to zero. Then, a matrix of order $n_{k} \times n$ can be obtained:

$$
U^{(k)}=\left(\mathrm{u}_{1}^{(\mathrm{k})}, \mathrm{u}_{2}^{(\mathrm{k})}, \cdots, \mathrm{u}_{\mathrm{n}}^{(\mathrm{k})}\right)=\left(\begin{array}{cccc}
\mathrm{u}_{11}^{(\mathrm{k})} & \mathrm{u}_{12}^{(\mathrm{k})} & \cdots & \mathrm{u}_{1 \mathrm{n}}^{(\mathrm{k})} \\
\mathrm{u}_{21}^{(\mathrm{k})} & \mathrm{u}_{22}^{(\mathrm{k})} & \cdots & \mathrm{u}_{2 \mathrm{n}}^{(\mathrm{k})} \\
\vdots & \vdots & \vdots & \vdots \\
\mathrm{u}_{\mathrm{n}_{\mathrm{i}} 1}^{(\mathrm{k})} & \mathrm{u}_{\mathrm{n}_{\mathrm{i}} 2}^{(\mathrm{k})} & \cdots & \mathrm{u}_{\mathrm{n}_{\mathrm{i}} \mathrm{n}}^{(\mathrm{k})}
\end{array}\right)
$$

where, column $j$ in $U^{(k)}$ is the single ranking vector of $n_{k}$ factors on layer $k$ relative to criterion $j$ on layer $k-1$. Then, the overall ranking of all factors on layer $k$ can be expressed as:

$$
w^{(k)}=\left(w_{1}^{(k)}, \cdots, w_{n}^{(k)}\right)^{T}
$$

Then,

$$
\begin{aligned}
& \mathbf{W}^{(k)}=U^{(k)} \mathbf{W}^{(k-1)} \\
& =\left(\begin{array}{cccc}
\mathbf{u}_{11}^{(\mathrm{k})} & \mathbf{u}_{12}^{(\mathrm{k})} & \cdots & \mathbf{u}_{1 \mathbf{n}}^{(\mathrm{k})} \\
\mathbf{u}_{21}^{(\mathrm{k})} & \mathbf{u}_{22}^{(\mathrm{k})} & \cdots & \mathbf{u}_{2 \mathbf{n}}^{(\mathrm{k})} \\
\vdots & \vdots & \vdots & \vdots \\
\mathbf{u}_{\mathbf{n}_{\mathrm{i}} 1}^{(\mathrm{k})} & \mathbf{u}_{\mathbf{n}_{\mathrm{i}} 2}^{(\mathrm{k})} & \cdots & \mathbf{u}_{\mathbf{n}_{\mathrm{i}} \mathrm{n}}^{(\mathrm{k})}
\end{array}\right)\left(\begin{array}{c}
\mathbf{w}_{1}^{(\mathrm{k}-1)} \\
\mathbf{w}_{2}^{(\mathrm{k}-1)} \\
\vdots \\
\mathbf{w}_{\mathbf{n}}^{(\mathrm{k}-1)}
\end{array}\right) \\
& =\left(\begin{array}{c}
\sum_{j-1}^{n} \mathbf{u}_{1 \mathbf{j}}^{(\mathrm{k})} \mathbf{W}_{\mathbf{j}}^{(\mathrm{k}-1)} \\
\sum_{j-1}^{n} \mathbf{u}_{2 \mathbf{j}}^{(\mathrm{k})} \mathbf{W}_{\mathbf{j}}^{(\mathrm{k}-1)} \\
\vdots \\
\sum_{j-1}^{n} \mathbf{u}_{\mathbf{n}_{\mathrm{i}} \mathbf{j}}^{(\mathrm{k})} \mathbf{w}_{\mathbf{j}}^{(\mathrm{k}-1)}
\end{array}\right)
\end{aligned}
$$

That is,

$$
\mathrm{W}_{i}^{(k)}=\sum_{\mathrm{j}-1}^{\mathrm{n}} u_{i j}^{(k)} w_{j}^{(k-1)}, i=1,2, \cdots, n
$$

Through the above steps, the score of each alternative (evaluation object) can be obtained. The score ranking determines the relative importance (suitability) of each object to the goal.

\section{CASE STUDY}

\subsection{Project overview}

The case project is Qingxihe Station, Line 6 of CRT. Lying below Yuegang Longitudinal Road and Yuegang Middle Road, the north-south oriented station crosses the interaction between the two roads, adopts an open cut double-layer rectangular frame, and has a $12 \mathrm{~m}$-long island platform. The total length, maximum clear width, and maximum clear height are $290.9 \mathrm{~m}, 24.3 \mathrm{~m}$, and $16.31 \mathrm{~m}$, respectively. There are two air ducts and six entrances and exits (two of which are reserved), all of which adopt open-cut rectangular frames.

\subsection{CGB-based foundation evaluation}

The main construction project of case is a metro station (an underground space project) and its ancillary works. The 
following items should be considered to evaluate the foundation of the project: uniformity of each layer, sorting of overburden composition, thickness of each layer, mechanical properties of each layer, groundwater effect, and adverse geological phenomena.

\subsubsection{Establishment of evaluation model}

Based on the above items, an AHP structure was set up, consisting of a goal layer, a criteria layer, and an alternative layer (as shown in Figure 3).
According to the complexity classification of geological environment in relevant codes, the importance of evaluation items in the project were ranked as mechanical properties, adverse geological phenomena, groundwater effect, uniformity, thickness, and sorting. On this basis, the judgement matrix of the criteria layer was established as Table 4.

The consistency of the judgement matrix was computed as 0.0156 , indicating that the matrix is sufficiently consistent.

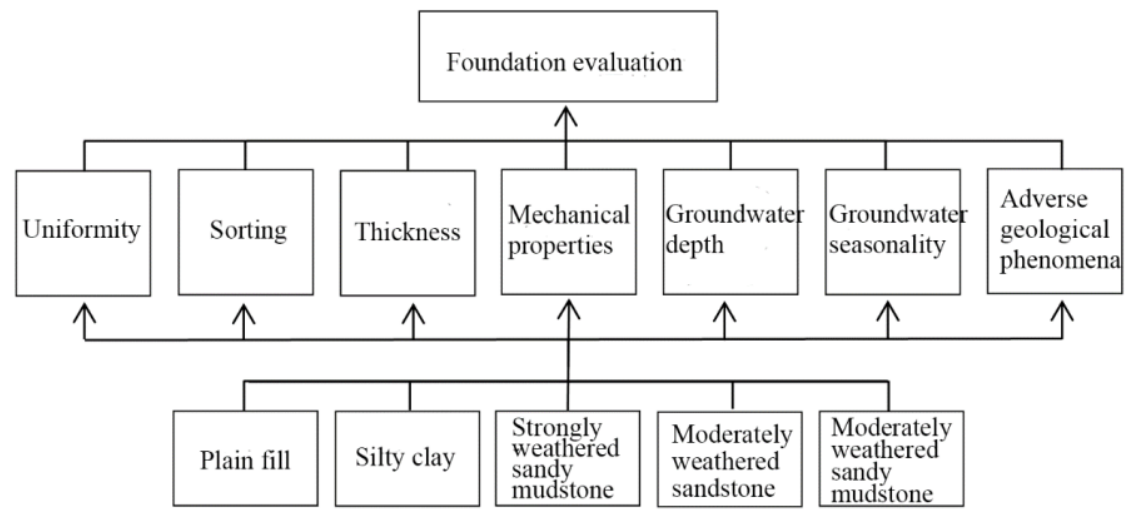

Figure 3. The AHP structure

Table 4. The judgement matrix of the criteria layer

\begin{tabular}{|c|l|c|c|c|c|c|c|}
\hline & Uniformity & Sorting & Thickness & $\begin{array}{c}\text { Mechanical } \\
\text { properties }\end{array}$ & $\begin{array}{c}\text { Groundwater } \\
\text { depth }\end{array}$ & $\begin{array}{c}\text { Groundwater } \\
\text { seasonality }\end{array}$ & $\begin{array}{c}\text { Adverse geological } \\
\text { phenomena }\end{array}$ \\
\hline Uniformity & & 3 & 2 & $1 / 7$ & $1 / 3$ & $1 / 3$ & $1 / 5$ \\
\hline Sorting & & & $1 / 2$ & $1 / 9$ & $1 / 5$ & $1 / 5$ & $1 / 7$ \\
\hline Thickness & & & & $1 / 8$ & $1 / 4$ & 3 & $1 / 6$ \\
\hline Mechanical properties & & & & 3 & & 1 & \\
\hline $\begin{array}{c}\text { Groundwater depth } \\
\text { Groundwater seasonality }\end{array}$ & & & & & & & $1 / 2$ \\
\hline $\begin{array}{c}\text { Adverse geological } \\
\text { phenomena }\end{array}$ & & & & & & \\
\hline
\end{tabular}

\subsubsection{Evaluation of each item}

After setting up the judgement matrix of the criteria layer, it is necessary to establish a judgement matrix of each item for plain fill, silty clay, strongly weathered sandy mudstone, moderately weathered sandstone, and moderately weathered sandy mudstone.

(1) Uniformity evaluation

Taking silty clay for example, the 3D model data of uniformity were imported to ArcScene. Then, the 3D Analyst tool was called from the ArcToolBox to convert the triangulated irregular network (TIN) model (as shown in Figure 4) of the upper and lower surfaces of the silty clay layer into grids. Then, a new grid map (as shown in Figure 5) was obtained by removing the grids of the upper and lower surfaces, revealing the thickness of silty clay across the construction site.

Next, the classification parameters were configured to reclassify the grids, producing a bar chart on the thickness of silty clay across the construction site (as shown in Figure 6). The bar chart visually displays the thickness data of silty clay in any location of the site. Then, the uniformity of the silty clay layer was judged by the standard deviation (SD) and the proportion of the thickness concentration area in the total area. The uniformities of the other layers were obtained in a similar manner. The uniformities of all layers are summed up in Table 5.
The plain fill is sporadically distributed in the construction site, showing a poor uniformity. Based on Table 5, the layers could be ranked in descending order of uniformity: silty clay, moderately weathered sandy mudstone, moderately weathered sandstone, strongly weathered sandy mudstone, and plain fill. On this basis, the judgement matrix of uniformity was established as Table 6.

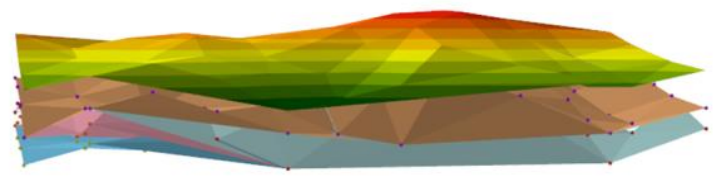

Figure 4. The TIN model of geological information

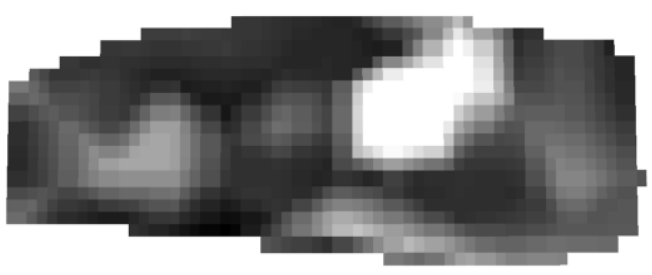

Figure 5. The grid map 


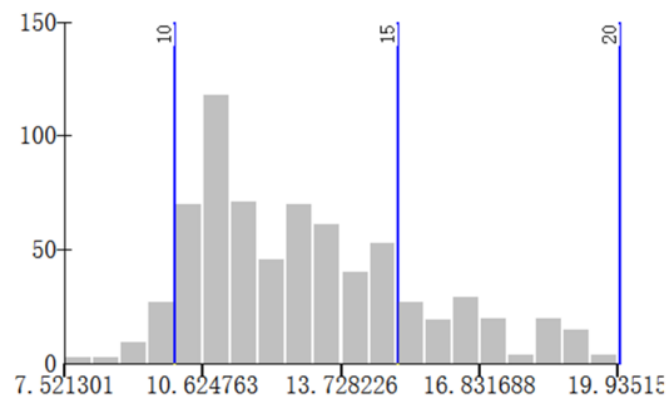

Figure 6. The bar chart of silty clay thickness

(2) Sorting evaluation

The sorting of each layer against the overburden directly affects the bearing capacity of the foundation, exerting a huge impact on the stability of buildings on the surface. The sorting quality mainly depends on the uniformity of the size of clastic particles. The more uniform the size, the better the sorting.

According to the project data, the plain fill is mainly composed of sandstone and sandy mudstone blocks (fragments). The size of the skeleton particles falls within 20$500 \mathrm{~mm}$, and could surpass $1 \mathrm{~m}$ in local areas. The content of these particles is generally $20-30 \%$. In relatively thick sections, the content of these blocks (fragments) increases significantly to $70-80 \%$ in local areas, while the particle size also increases. In the plain fill, the skeleton particles have a nonuniform distribution of content, and significant changes in particle size. By contrast, there is no obvious inclusion in silty clay. This layer mainly consists of clay, with few hard matters.

Through the above analysis, the layers could be ranked in descending order of sorting: moderately weathered sandy mudstone/moderately weathered sandstone, strongly weathered sandy mudstone, silty clay, and plain fill. On this basis, the judgement matrix of sorting was established as Table 7.

Table 5. The uniformities of all layers

\begin{tabular}{cccccccc}
\hline No. & Layers & $\begin{array}{c}\text { Min. } \\
(\mathbf{m})\end{array}$ & $\begin{array}{c}\text { Max. } \\
(\mathbf{m})\end{array}$ & $\begin{array}{c}\text { Mean } \\
(\mathbf{m})\end{array}$ & SD & $\begin{array}{c}\text { Thickness } \\
\text { concentration area (m) }\end{array}$ & $\begin{array}{c}\text { Proportion of thickness } \\
\text { concentration area }(\%)\end{array}$ \\
\hline 1 & Silty clay & 7.52 & 19.94 & 12.95 & 2.49 & $10-15$ & 75 \\
2 & Strongly weathered sandy mudstone & 5.76 & 25.40 & 7.38 & 4.64 & $5-10$ & 45 \\
3 & Moderately weathered sandstone & 0 & 26.92 & 5.22 & 4.88 & $0-5$ & 51 \\
4 & Moderately weathered sandy mudstone & 1.12 & 13.40 & 2.94 & 3.38 & $0-5$ & 57 \\
\hline
\end{tabular}

Table 6. The judgement matrix of uniformity

\begin{tabular}{|c|c|c|c|c|c|}
\hline & Plain fill & Silty clay & $\begin{array}{c}\text { Strongly weathered } \\
\text { sandy mudstone }\end{array}$ & $\begin{array}{c}\text { Moderately } \\
\text { weathered sandstone }\end{array}$ & $\begin{array}{c}\text { Moderately weathered } \\
\text { sandy mudstone }\end{array}$ \\
\hline Plain fill & & $1 / 9$ & $1 / 3$ & $1 / 5$ & $1 / 7$ \\
\hline Silty clay & & & 4 & 3 & 2 \\
\hline Strongly weathered sandy mudstone & & & & $1 / 2$ & $1 / 4$ \\
\hline Moderately weathered sandstone & & & & & $1 / 2$ \\
\hline Moderately weathered sandy mudstone & & & & \\
\hline
\end{tabular}

Table 7. The judgement matrix of sorting

\begin{tabular}{|c|c|c|c|c|c|}
\hline & Plain fill & Silty clay & $\begin{array}{c}\text { Strongly weathered } \\
\text { sandy mudstone }\end{array}$ & $\begin{array}{c}\text { Moderately weathered } \\
\text { sandstone }\end{array}$ & $\begin{array}{c}\text { Moderately weathered } \\
\text { sandy mudstone }\end{array}$ \\
\hline Plain fill & & $1 / 3$ & $1 / 8$ & $1 / 9$ & $1 / 9$ \\
\hline Silty clay & & & $1 / 7$ & $1 / 8$ & $1 / 8$ \\
\hline Strongly weathered sandy mudstone & & & & $1 / 2$ & $1 / 2$ \\
\hline Moderately weathered sandstone & & & & & 1 \\
\hline Moderately weathered sandy mudstone & & & & & \\
\hline
\end{tabular}


Table 8. The judgement matrix of thickness

\begin{tabular}{|c|c|c|c|c|c|}
\hline & Plain fill & Silty clay & $\begin{array}{c}\text { Strongly weathered } \\
\text { sandy mudstone }\end{array}$ & $\begin{array}{c}\text { Moderately } \\
\text { weathered sandstone }\end{array}$ & $\begin{array}{c}\text { Moderately weathered } \\
\text { sandy mudstone }\end{array}$ \\
\hline Plain fill & & $1 / 7$ & $1 / 5$ & $1 / 3$ & $1 / 9$ \\
\hline Silty clay & & & 3 & 2 & $1 / 3$ \\
\hline Strongly weathered sandy mudstone & & & & 2 & $1 / 2$ \\
\hline Moderately weathered sandstone & & & & & $1 / 3$ \\
\hline Moderately weathered sandy mudstone & & & & & \\
\hline
\end{tabular}

Table 9. The mechanical parameters

\begin{tabular}{|c|c|c|c|c|}
\hline Layers & Silty Plain & Moderately & Strongly weathered & Moderately weathered \\
\hline Typ & clay fill & weathered sandstone & sandy muds & sandy muds \\
\hline Standard bearing capacity 0 & $130 * 100 *$ & 1200 & $350 *$ & 850 \\
\hline
\end{tabular}

Table 10. The judgement matrix of mechanical properties

\begin{tabular}{|c|c|c|c|c|c|}
\hline & Plain fill & Silty clay & $\begin{array}{c}\text { Strongly weathered } \\
\text { sandy mudstone }\end{array}$ & $\begin{array}{c}\text { Moderately } \\
\text { weathered sandstone }\end{array}$ & $\begin{array}{c}\text { Moderately weathered } \\
\text { sandy mudstone }\end{array}$ \\
\hline Plain fill & & $1 / 2$ & $1 / 4$ & $1 / 9$ & $1 / 8$ \\
\hline Silty clay & & & $1 / 2$ & $1 / 9$ & $1 / 8$ \\
\hline Strongly weathered sandy mudstone & & & & $1 / 4$ & $1 / 3$ \\
\hline Moderately weathered sandstone & & & & & 2 \\
\hline Moderately weathered sandy mudstone & & & & & \\
\hline
\end{tabular}

\section{(5) Groundwater effect evaluation}

Groundwater effect was included in foundation evaluation, because most structures of the project are underground and affected by groundwater. The spatial information of survey points was imported to ArcGIS, and then projected to the geological model of the site, producing a 3D model of groundwater depth (as shown in Figure 7).

Based on project data and the empirical values of the region, the permeability coefficients of plain fill, silty clay, strongly weathered sandy mudstone, moderately weathered sandstone, and moderately weathered sandy mudstone were obtained as $5 \times 10^{-5} \mathrm{~cm} / \mathrm{s}, 5 \times 10^{-6} \mathrm{~cm} / \mathrm{s}, 2 \times 10^{-5} \mathrm{~cm} / \mathrm{s}, 1.2 \times 10^{-5} \mathrm{~cm} / \mathrm{s}$, and $2 \times 10^{-}$ ${ }^{6} \mathrm{~cm} / \mathrm{s}$, respectively.

Through the above analysis, the layers could be ranked in descending order of groundwater effect: moderately weathered sandy mudstone, silty clay, moderately weathered sandstone, strongly weathered sandy mudstone, and plain fill. On this basis, the judgement matrix of groundwater effect was established as Table 11.

(6) Adverse geological phenomena evaluation

Adverse geological phenomena usually refer to the geological phenomena in and around the construction site that are not conducive to engineering construction, such as landslides, debris flows, ground collapses, and hidden karsts.

The project data show that the construction site, located on the east wing of the Yuelai syncline, has a normal stratigraphic sequence, without adverse geological effects like landslides, ground collapses, or faults. Hence, the factors in the judgement matrix of adverse geological phenomena are of equal importance.

\subsubsection{Results of foundation evaluation}

Based on the evaluation system and the judgment matrix of the criteria layer, the suitability of each layer as supporting layer of the foundation was calculated according to the results of each judgement matrix, yielding the results of foundation evaluation.

(1) Display of weight distribution
Through single ranking and overall ranking, the weights of all criteria of our model were obtained (as shown in Figure 8).

(2) Results of the judgement matrix of the criteria layer

The results of the judgement matrix of the criteria layer are presented in Table 12 below.

(3) Evaluation results and comparison chart

The criteria weights were coupled with the results of the judgement matrix of the criteria layer to produce the suitability of different layers (Table 13, Figure 9). Obviously, moderately weathered sandstone and moderately weathered sandy mudstone are the suitable supporting layers of the foundation.

\subsubsection{Results analysis}

In the survey report of the metro station, there is a complete section of foundation evaluation. This section reports that, the construction site is distributed with silty clay and a small amount of plain fill, sandstone, and sandy mudstone, as confirmed by drilling, geological mapping, and survey. According to the engineering geological features of soil-rock mass in the site, the upper fill cannot serve as the supporting layer of the foundation, due to the great variation in thickness, poor uniformity, and low strength. The silty clay in the lower part will cause differential settlement, if it acts as the supporting layer: the silty clay varies greatly in thickness, and exists as lenticles or thins out in local areas, not to mention its poor strength. However, the moderately weathered rocks in the lower part are an ideal supporting layer of the foundation, thanks to their high strength and stability. The conclusion of the report agrees well with our AHP results.

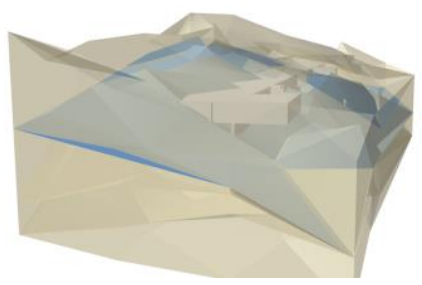

Figure 7. The model of groundwater depth 
Table 11. The judgement matrix of groundwater effect

\begin{tabular}{|c|c|c|c|c|c|}
\hline & Plain fill & Silty clay & $\begin{array}{c}\text { Strongly weathered } \\
\text { sandy mudstone }\end{array}$ & $\begin{array}{c}\text { Moderately } \\
\text { weathered sandstone }\end{array}$ & $\begin{array}{c}\text { Moderately weathered } \\
\text { sandy mudstone }\end{array}$ \\
\hline Plain fill & & $1 / 7$ & $1 / 3$ & $1 / 5$ & $1 / 9$ \\
\hline Silty clay & & & $1 / 2$ & 2 & $1 / 3$ \\
\hline Strongly weathered sandy mudstone & & & $1 / 2$ & $1 / 4$ \\
\hline Moderately weathered sandstone & & & & $1 / 2$ \\
\hline Moderately weathered sandy mudstone & & & & \\
\hline
\end{tabular}

Table 12. The results of the judgement matrix of the criteria layer

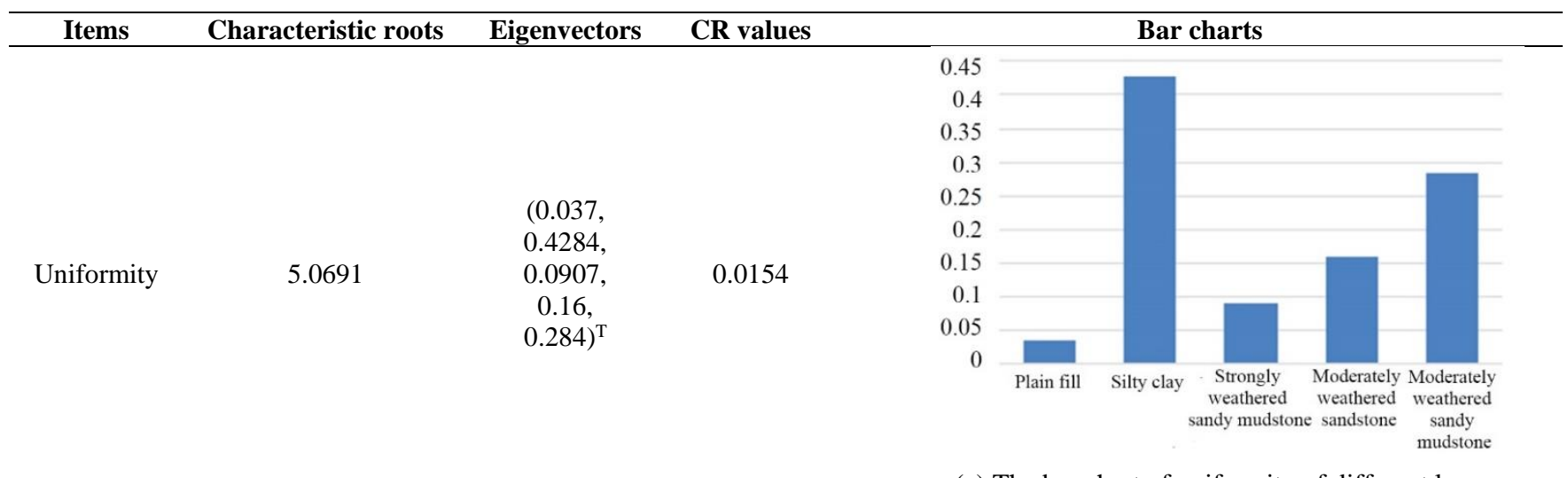

(a) The bar chart of uniformity of different layers

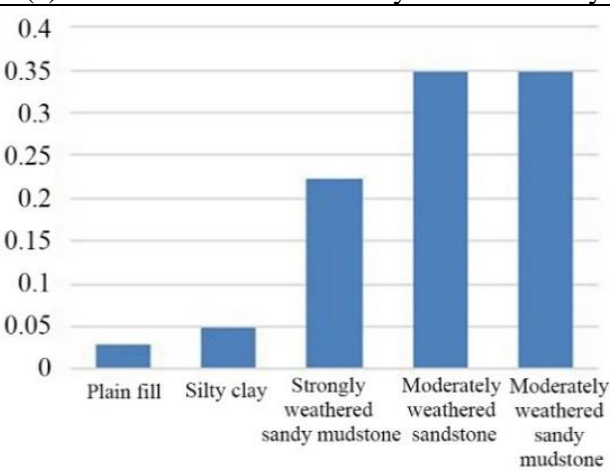

0.0293

0.0496 ,

Sorting

5.1700

0.349 ,

$0.349)^{\mathrm{T}}$ (b) The bar chart of sorting of different layers

0.0379

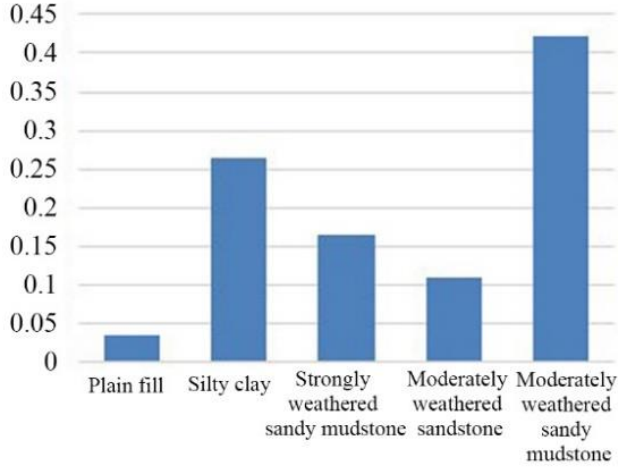

(c) The bar chart of thickness of different layers

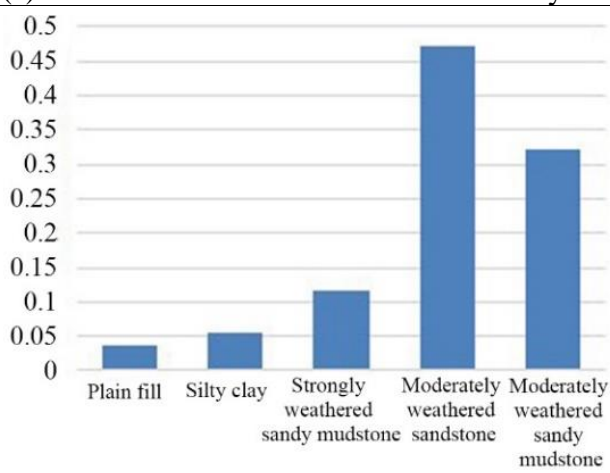

(d) The bar chart of mechanical properties of different layers 


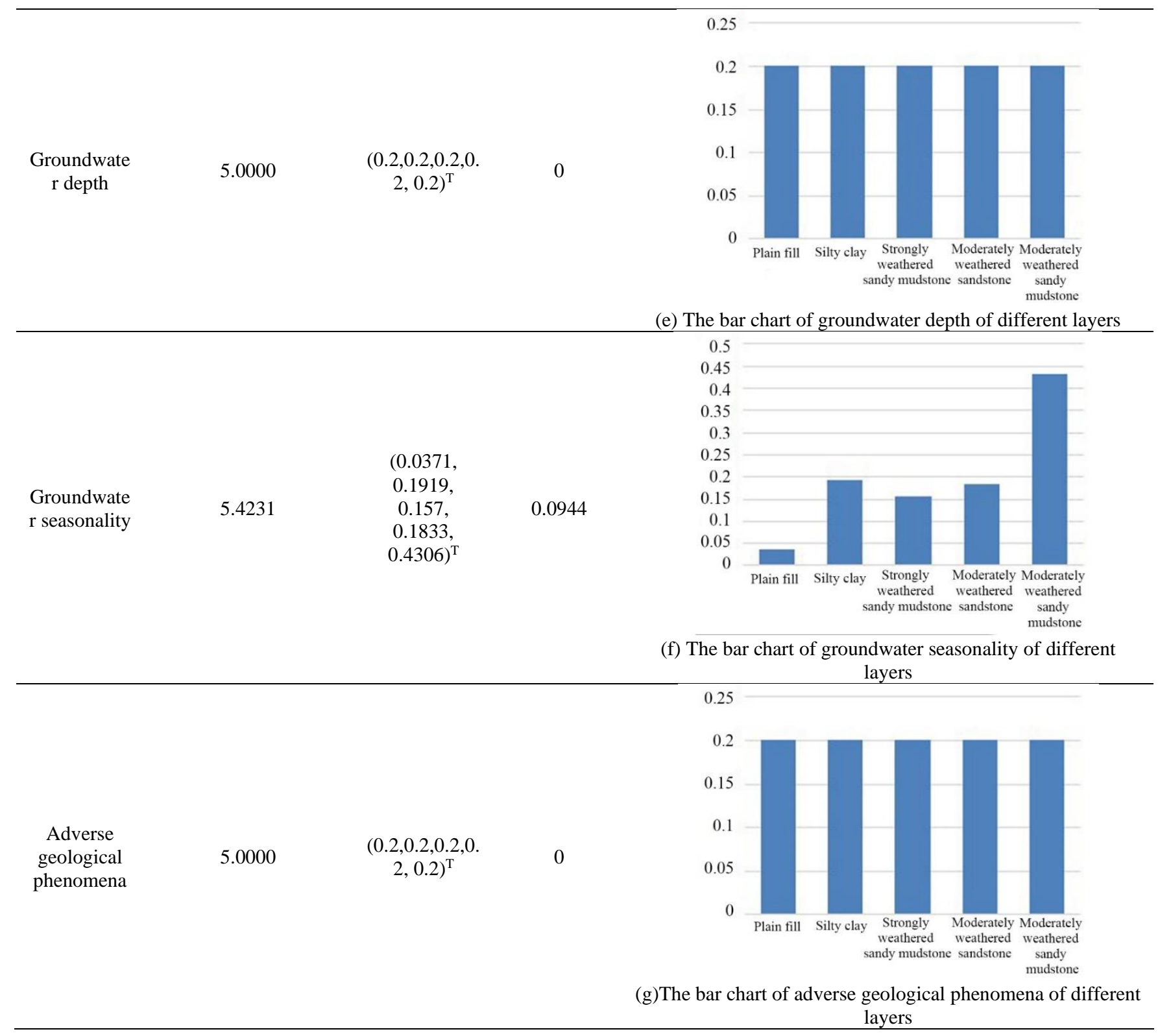

Table 13. The suitability of each layer

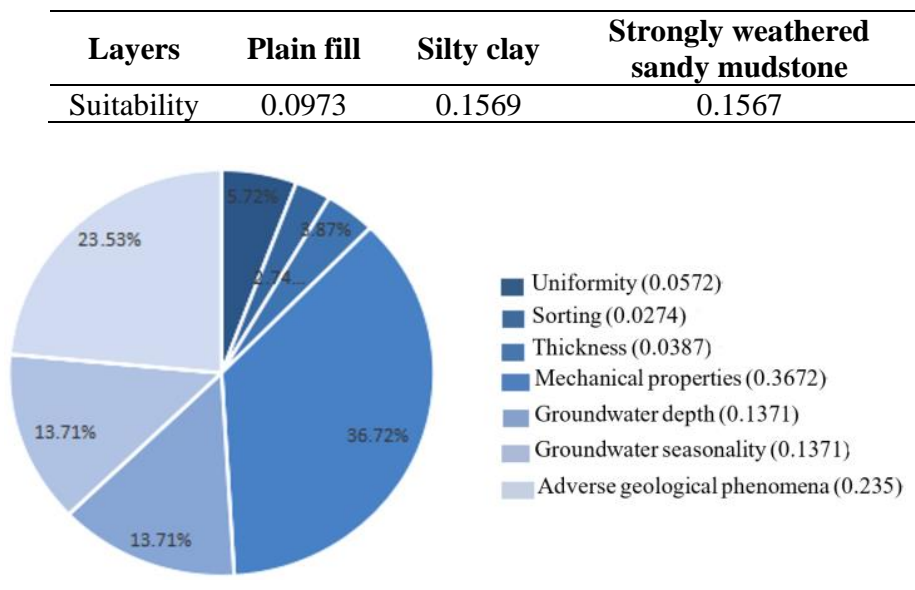

Figure 8. The pie chart of weight distribution

\section{CONCLUSIONS}

This paper successfully visualizes foundation evaluation based on CGB technology integration and the AHP. Multiple influencing factors were quantified, making the evaluation process and results more reliable. The evaluation process is completely visible, and the evaluation results are highly accurate, allowing every construction party to check the 
judgement of each factor easily and independently. The research findings provide a good reference for the selection of the supporting layer of foundations in urban rail transit projects.

\section{ACKNOWLEDGMENT}

This work was supported by Chongqing Social Career and People's Livelihood Guarantee Science and Technology Innovation Special Program (cstc2016shmszx30017); Chongqing Fundamental and Frontier Research (cstc2017jcyjAX0260); Chongqing Graduate Education Innovation Fund (CYS18227).

\section{REFERENCES}

[1] Wang, H., Pan, Y., Luo, X. (2019). Integration of BIM and GIS in sustainable built environment: A review and bibliometric analysis. Automation in Construction, 103: 41-52. https://doi.org/10.1016/j.autcon.2019.03.005

[2] Colucci, E., De Ruvo, V., Lingua, A., Matrone, F., Rizzo, G. (2020). HBIM-GIS integration: From IFC to cityGML standard for damaged cultural heritage in a multiscale 3D GIS. Applied Sciences, 10(4): 1356. https://doi.org/10.3390/app10041356

[3] Stouffs, R., Tauscher, H., Biljecki, F. (2018). Achieving complete and near-lossless conversion from IFC to CityGML. ISPRS International Journal of GeoInformation, 7(9): 355-163. https://doi.org/10.3390/ijgi7090355

[4] Jusuf, S.K., Mousseau, B., Godfroid, G., Soh, J.H.V. (2017). Path to an integrated modelling between IFC and CityGML for neighborhood scale modelling. Urban Science, $1(3)$ : https://doi.org/10.3390/urbansci1030025

[5] Deng, Y., Cheng, J. C., Anumba, C. (2016). Mapping between BIM and 3D GIS in different levels of detail using schema mediation and instance comparison. Automation in Construction, 67: 1-21. https://doi.org/10.1016/j.autcon.2016.03.006

[6] Diakite, A.A., Zlatanova, S. (2020). Automatic georeferencing of BIM in GIS environments using building footprints. Computers, Environment and Urban Systems, 80: 101453 https://doi.org/10.1016/j.compenvurbsys.2019.101453

[7] Tsilimantou, E., Delegou, E.T., Nikitakos, I.A., Ioannidis, C., Moropoulou, A. (2020). GIS and BIM as integrated digital environments for modeling and monitoring of historic buildings. Applied Sciences, 10(3): 1078. https://doi.org/10.3390/app10031078

[8] Hijazi, I., Donaubauer, A., Kolbe, T.H. (2018). BIM-GIS integration as dedicated and independent course for geoinformatics students: Merits, challenges, and ways forward. ISPRS International Journal of GeoInformation, $\quad 7(8)$ : 319 https://doi.org/10.3390/ijgi7080319

[9] Koutamanis, A. (2020). Dimensionality in BIM: Why BIM cannot have more than four dimensions? Automation in Construction, 114: 103153. https://doi.org/10.1016/j.autcon.2020.103153

[10] Kumar, K., Labetski, A., Ohori, K.A., Ledoux, H., Stoter, J. (2019). The LandInfra standard and its role in solving the BIM-GIS quagmire. Open Geospatial Data, Software and Standards, 4(1): 1-16. https://doi.org/10.1186/s40965-019-0065-z

[11] Arroyo Ohori, K., Diakité, A., Krijnen, T., Ledoux, H., Stoter, J. (2018). Processing BIM and GIS models in practice: experiences and recommendations from a GeoBIM project in the Netherlands. ISPRS International Journal of Geo-Information, 7(8): 311-318. https://doi.org/10.3390/ijgi7080311

[12] Zhang, L., El-Gohary, N.M. (2020). Automated IFCbased building information modelling and extraction for supporting value analysis of buildings. International Journal of Construction Management, 20(4): 269-288. https://doi.org/10.1080/15623599.2018.1484850

[13] Mirarchi, C., Pavan, A., De Marco, F., Wang, X., Song, Y. (2018). Supporting facility management processes through end-users' integration and coordinated BIM-GIS technologies. ISPRS International Journal of GeoInformation, 7(5): 191-197. https://doi.org/10.3390/ijgi7050191

[14] Marzouk, M., Othman, A. (2020). Planning utility infrastructure requirements for smart cities using the integration between BIM and GIS. Sustainable Cities and Society, 57: 120-126. https://doi.org/10.1016/j.scs.2020.102120

[15] D’Amico, F., Calvi, A., Schiattarella, E., Di Prete, M., Veraldi, V. (2020). BIM and GIS data integration: A novel approach of technical/environmental decisionmaking process in transport infrastructure design. Transportation Research Procedia, 45: 803-810. https://doi.org/10.1016/j.trpro.2020.02.090

[16] Liu, B., Sun, X. (2018, March). Application analysis of BIM technology in metro rail transit. In IOP Conference Series: Earth and Environmental Science, 128: 28-31. https://doi.org/10.1088/1755-1315/128/1/012028

[17] Chen, G., Xue, M., Hu, Z.J., Liu, Y.Z. (2019). GIS+BIM spatial framework for urban rail transit project. Bulletin of Surveying and Mapping, (S2): 262-266. https://doi.org/10.13474/j.cnki.11-2246.2019.0639

[18] He, G.F., Luo, X.Q., Zhang, H. (2019). Technology of early warning and forecast of metro tunnel safety based on BIM and GIS. Urban Mass Transit, (7): 161-164. https://doi.org/10.16037/j.1007-869x.2019.07.038

[19] Dzikunoo, E.A., Vignoli, G., Jørgensen, F., Yidana, S. M., Banoeng-Yakubo, B. (2020). New regional stratigraphic insights from a 3D geological model of the Nasia sub-basin, Ghana, developed for hydrogeological purposes and based on reprocessed B-field data originally collected for mineral exploration. Solid Earth, 11(2): 349-361. https://doi.org/10.5194/se-11-349-2020

[20] Chen, L., Wang, H., Xu, X., Zhang, Y., Wang, C., Song, J., Han, L. (2019). Geological exploration using integrated geophysical methods in tunnel: A case. Geotechnical and Geological Engineering: An International Journal, 38(2): 1111-1119. https://doi.org/10.1007/s10706-019-01075-w

[21] Ku, T., Palanidoss, S., Zhang, Y., Moon, S.W., Wei, X., Huang, E.S., Goh, K.H. (2020). Practical configured microtremor array measurements (MAMs) for the geological investigation of underground space. Underground Space, 19: 1-12. https://doi.org/10.1016/j.undsp.2020.01.004

[22] Kanik, M., Ersoy, H. (2019). Evaluation of the engineering geological investigation of the Ayvali dam 
site (NE Turkey). Arabian Journal of Geosciences, 12(3): 89. https://doi.org/10.1007/s12517-019-4243-1

[23] Soldo, L., Vendramini, M., Eusebio, A. (2019). Tunnels design and geological studies. Tunnelling and Underground Space Technology, 84, 82-98. https://doi.org/10.1016/j.tust.2018.10.013

[24] Di Giulio, G., Ercoli, M., Vassallo, M., Porreca, M. (2020). Investigation of the Norcia basin (Central Italy) through ambient vibration measurements and geological surveys. Engineering Geology, 267: 105501. https://doi.org/10.1016/j.enggeo.2020.105501
[25] Zhang, C.C., Gu, P., Cao, F.X. (2020). Discussion on the hazards of hydrogeological problems in engineering geological survey. Construction \& Design for Engineering, 40-41. https://doi.org/10.13616/j.cnki.gcjsysj.2020.03.220

[26] Gao, Y., Liang, G.H., Zhou, Y.Y. (2019). Exploration of geotechnical engineering investigation under complex topographical and geological conditions. Frontiers Research of Architecture and Engineering, 2(4): 20-23. https://doi.org/10.30564/frae.v2i4.1512 